\title{
SINERGI ORANG TUA DAN PERGURUAN TINGGI HINDU DALAM MENINGKATKAN MUTU PERGURUAN TINGGI HINDU
}

\author{
Oleh : \\ Ketut Bali Sastrawan \\ Dosen Fakultas Dharma Acarya IHDN Denpasar
}

\begin{abstract}
National character and civilization building cannot be separated from the education institution. As a place for producing intellectuals, education institutions might be regarded as the "second homes" in which students study to develop their competencies. They are the places in which the collaboration from the students' parents is needed in order to create a good learning atmosphere. So far the Hindu education institutions receive lack of this kind of collaboration. As a solution, it is necessary to provide more space for the students' parents to contribute to the Hindu higher education improvement. Such a place is necessary for a good communication as in a particular situation students' parents should be involved in improving the quality of the education and avoiding opposition.
\end{abstract}

Keywords : collaboration, parents, Hindu higher education, quality improvement

\section{PENDAHULUAN}

Peningkatan mutu penyelenggaraan pendidikan di Perguruan Tinggi dititik beratkan pada penciptaan proses pembelajaran yang kondusif, efektif, dan efisien, agar dapat memberikan bekal kemampuan akademis dan profesional kepada mahasiswa, sehingga lulusan yang dihasilkan siap bersaing di pasar global. UU No.20/2003 Sistem Pendidikan Nasional Pasal 3, menguraikan fungsi Pendidikan Nasional adalah mengembangkan kemampuan dan membentuk watak serta peradaban bangsa yang bermartabat dalam rangka mencerdaskan kehidupan bangsa dan tujuannya adalah untuk berkembangnya potensi peserta didik agar menjadi manusia yang beriman dan bertakwa kepada Tuhan Yang Maha Esa, berakhlak mulia, sehat, berilmu, cakap, kreatif, mandiri, dan menjadi warga negara yang demokratis serta bertanggung jawab.
Pemikiran bagaimana menempatkan pendidikan tinggi sebagai ujung tombak perubahan bangsa sebenarnya sudah berlangsung sejak lama. Berulang kali para pembuat kebijakan pendidikan tinggi dihadapkan pada pilihan-pilihan antara pemerataan pendidikan atau pengembangan pusat keunggulan (centers of excellence). Memasuki milenium ketiga, tampaknya, pilihan telah ditentukan. Kita tidak dapat mewujudkan keunggulan di segala bidang, di semua tempat, dan pada waktu yang bersamaan. Karena itu, strategi pengembangan pendidikan tinggi diarahkan pada pemberian peluang kepada perguruan tinggi yang mempunyai potensi dan kapasitas untuk mengembangkan dirinya meraih keunggulan kompetitif. Yakni keunggulan akademik atau yang sering kita sebut sebagai academic excellence (Joko, 2012) 
Pembentukan watak serta peradaban bangsa tidak bisa lepas dari peran Lembaga Pendidikan sebagai garda terdepan dalam rangka mencerdaskan kehidupan bangsa. Perguruan Tinggi sebagai lembaga yang menghasilkan intelektual baik ditingkat Diploma maupun Sarjana merupakan rumah kedua bagi mahasiswa untuk belajar dan menuntut ilmu, serta mengembangkan potensi yang dimiliki. Keberhasilan mahasiswa dalam pembelajaran tidak bisa lepas dari peran Perguruan Tinggi dalam meberikan pelayanan. Dosen memiliki peran yang sangat besar dalam membentuk karakter mahasiswa dan menghasilkan lulusan yang professional sesuai almamater

Berkenaan dengan terbatasnya waktu mahasiswa di kampus, maka pengembangan diri mahasiswa sedikit tidaknya dipengaruhi oleh keluarga dan masyarakat. Untuk menyentuh perkembangan aspek ketakwaan terhadap Tuhan Yang Maha Esa, berakhlak mulia, sehat, berilmu, cakap, kreatif, mandiri, dan menjadi warga negara yang demokratis serta bertanggung jawab sesuai amanat undangundang No.20/2003, maka diperlukan peran dari seseorang yang dekat dengan mahasiswa ketika keluar dari lingkungan kampus.

Khususnya di Perguruan Tinggi Hindu, peran orangtua sangatlah besar. Mengingat pendidikan Hindu bukan hanya menuntut seorang mahasiswa Hindu hanya cerdas dalam teori, namun juga mengimplementasikan nilainilai moral keagamaan. Mahasiswa tidak hanya dituntut untuk memiliki gelar akademis, tetapi juga dituntut memberikan keteladanan serta keberanian dalam berbicara masalah Dharma.

Lebih menghusus tentang kehidupan beragama Hindu di Bali, dimana tuntutan masyarakat Hindu semakin besar. Mahasiswa bukan hanya dituntut untuk paham terhadap filsafat agama, namun juga ahli dalam praktik ritual keagamaan. Kehidupan Beragama di Bali yang sangat kompleks sesuai dengan desa, kala, dan patra, semakin memperberat tantangan dunia pendidikan Hindu. Dalam satu Kecamatan, pola ritual serta sarana keagamaan umat Hindu bisa sangat berbeda, apalagi dalam satu Kabupaten maupun Propinsi.

Berkaitan dengan permasalahan diatas, maka sangat diperlukan masukan masyarakat tentang bagaimana membangun kehidupan Perguruan Tinggi kedepan. Dalam hal ini orangtua sebagai salah satu perwujudan masyarakat yang paling dekat dengan kehidupan kampus akan sangat memberikan peran dalam mewujudkan Perguruan Tinggi Hindu yang ideal. Peran orangtua bukan hanya dalam hal pendanaan Perguruan Tinggi, namun juga dapat dijadikan sumber ide dan gagasan bagi pengembangan Perguruan Tinggi kedepan.

\section{PEMBAHASAN}

\subsection{Sinergi Orang Tua dan Perguruan Tinggi Hindu Dalam Perkembangan Intelektual Mahasiswa}

Membangun sinergi orangtua dan Perguauan Tinggi Hindu ibarat membangun jembatan antara dua tempat yang dipisahkan oleh sungai. Sebelumnya keduanya sudah terhubung namun untuk sampai harus mempergunakan sampan yang memerlukan waktu lama. Kesadaran antara kedua komponen ini untuk saling bersinergi akan membawa peluang semakin besar untuk menciptakan iklim pembelajaran yang baik serta kemajuan Perguruan Tinggi kedepan. Sebagaimana membangun sebuah sinergi yang baik antara orangtua dan Perguauan Tinggi Hindu, harus dipahami bahwa orangtua memiliki kewajiban untuk mengetahui bagaimana Perguruan Tinggi Hindu membangun visi dan misinya. Selanjutnya yang harus disadari oleh orangtua bahwa kemajuan Perguruan tidak bisa terlepas dari peran orangutan.

Keluarga sebagai pendidik memiliki beberapa fungsi yaitu fungsi dalam perkembangan kepribadian anak dan mendidik anak dirumah. Fungsi keluarga 
dalam pembentukan kepribadian dan mendidik anak di rumah: (1) Sebagai pengalaman pertama masa kanak-kanak. (2) Menjamin kehidupan emosional anak. (3) Menanamkan dasar pendidikan moral anak. (4) Meletakkan dasar-dasar pendidikan agama. (5) Bertanggung jawab dalam memotivasi dan mendoromg keberhasilan anak. (6) Memberikan kesempatan belajar dengan mengenalkan berbagai ilmu pengetahuan dan keterampilan yang berguna bagi kehidupan kelak sehingga ia mampu menjadi manusia dewasa yang mandiri. (7) Menjaga kesehatan anak sehingga dengan nyaman menjalankan proses belajar yang utuh. (8) Memberikan kebahagiaan dunia akhirat dengan memberikan pendidikan agama sesuai dengan ketentuan Tuhan, sebagai tujuan akhir manusia. (Hasbullah, 1997)

Peran yang dibangun orangtua terhadap anak yang sudah masuk jenjang perguruan tinggi (dewasa) memang tidak seperti ketika anak masih usia sekolah. Sikap orangtua yang terlalu mengintervensi kebutuhan anak justru bisa berdampak buruk bagi perkembangan anak. Dalam kitab dharma sastra sloka 80 "Perlakuan seorang anak sebagai raja sampai usia lima tahun, dalam waktu sepuluh tahun( sesudah usia lima tahun) sebagai pembantu, pada usia enam belas tahun (keatas), bagaikan sahabat. Demikian (ajaran) Putrasasana (ketentuan untuk orang tua mendidik anak-anaknya"(Suparta, 2012). Dilihat dari umur, usia anak masuk jenjang perguruan tinggi antara 18-19 tahun. Bila dikaitkan dengan tahap perkemangan, pada usia 18-20 tahun anak masih berada dalam tahap perkembangan remaja.

Tahap perkembangan remaja dimulai dari usia 14-20 tahun. Dalam tahap ini kualitas kehidupan anak diwarnai dengan dorongan seksual yang kuat. Keadaan ini membuat orang mulai tertarik dengan orang yang berlainan jenis kelamin. Anak dalam tahap ini juga mulai mengembangkan pengertian tentang kenyataan hidup serta mulai memikirkan pola tingkah laku yang bermoral.Anak juga mulai memikirkan tentang kepentingan sosial dan kepentingan pribadinya. Berhubungan dengan berkembangnya keinginan dan emosi yang dominan dalam pribadi anak pada masa ini menyebabkan anak sering mengalami kegoncangan dalam dirinya (Wasty, 2006:68-76)

Mengingat kondisi anak pada usia awal masuk perguruan tinggi yang masih dalam tahap perkembangan remaja, membangun komunikasi yang baik dengan seorang anak yang duduk di Perguruan Tinggi mutlak diperlukan. Pemikiran seorang mahasiswa tidak dapat dikekang oleh siapapun. Pola asuh sebagai layaknya sahabat dilakukan baik dirumah maupun di dunia kampus. Pertimbangan-pertimbangan logis dengan memberikan kesempatan besar bagi anak usia ini sangat diperlukan. Dengan membangun komunikasi yang baik dengan anak usia ini dimaksudkan agar anak belajar bagaimana mengelola kehidupannya secara mandiri. Kondisi anak yang mulai memikirkan tentang kepentingan sosial dan kepentingan pribadinya, menyebabkan faktor lingkungan berperan besar terhadap pembentukan karakter anak.

Guna mewujudkan lingkungan sosial yang baik di perguruan tinggi, perlu diefektifkan kegiatan-kegiatan penunjang akademik. Mahasiswa labih banyak dilibatkan dalam berbagai kegiatan seperti penelitian, pemberdayaan masyarakat, maupun kegiatan lainnya. Hal ini akan memberikan kesempatan kepada mahasiswa untuk bereksplorasi dan berinteraksi lebih dekat dengan dosennya. Komunikasi yang dibangun antara mahasiswa dan dosen sedikit tidaknya akan memberntuk karakter siswa 
menjadi lebih baik. Dipihak lain orangtua juga harus memberikan kontrol terhadap mahasiswa ketika berada diluar kampus. Beberapa situasi seperti anak berada jauh dari orangtua tidak bisa dijadikan alasan orangtua untuk tidak membangun komunikasi dengan anak. Apalagi dengan situasi teknologi dan komunikasi yang semakin canggih, menjadikan jarak bukan lagi sebagai masalah dalam berinteraksi. Perhatian orangtua akan memberikan dukungan moril yang sangat besar bagi seorang anak dalam menyelesaikan pendidikannya. Lingkungan dalam berinteraksi yang dipilih seorang anak akan sangat didukung oleh seberapa besar perhatian orangtua terhadap anak.

\subsection{Sinergi Orang Tua Dan Perguruan Tinggi Hindu Dalam Membangun Spiritual Mahasiswa}

Membangun mutu perguruan tinggi Agama tidak dapat dilepaskan dari bagaimana membangun mutu identitas agama yang melekat didalamnya. Mahasiswa Hindu tidak bisa dilepaskan dari identitas yang melekat dalam dirinya sebagai seorang intelektual sekaligur praktisi agama Hindu. Mahasiswa Hindu harus mencerminkan sikap dan tingkahlaku seorang yang mendalami ajaran agama Hindu. Anggapan masyarakat bahwa seorang mahasiswa yang kuliah di Perguruan Tinggi Hindu harus bisa memberikan tauladan, mengajarkan kebenaran dan memecahkan masalah-masalah keagamaan. Anggapan seperti itu harus dijawab oleh penyelenggara pendidikan di Perguruan Tinggi Hindu dengan melahirkan mahasiswa-mahasiswa yang intelek dan bertanggungjawab terhadap identitas yang melekat dalam statusnya sebagai pelajar serta gelar yang diperolehnya ketika tamat dari Perguruan Tinggi Hindu.

Fenomena yang terjadi, banyak mahasiswa yang kuliah di perguruan Tinggi Hindu tidak bisa menunjukkan sikap yang daiharapkan di masyarakat. Kondisi ini tentunya harus menjadi perhatian serius bukan hanya dari penyelenggara pendidikan di Perguruan Tinggi Hindu saja, namun juga orangtua mahasiswa dirumah. Melihat kenyataan bahwa waktu berinteraksi mahasiswa lebih banyak dilakukan di rumah dan masyarakat sekitarnya. Oleh karena itu peran orangtua dalam menciptakan iklim social kemasyarakatan yang baik bagi mahasiswa sangat diperlukan.

Perguruan Tinggi Hindu berperan besar guna mmmenciptakan iklim spiritual salah satunya dengan mengimplementasikan ajaran Tri Hita Karana dilingkungan kampus. Kondisi parahya-ngan dibangun dengan pelaksanaan puja tri sandhya, mengefektifkan UKM acara keagamaan dalam membuat sarana persembahyangan, serta kuliah dengan berpakaian sembahyang setiap hari suci keagamaan termasuk purnama dan tilem. Identitas keagamaan juga ditunjukkan dengan mengefektifkan UKM Dharma Gita dan Dharma Wacana. Setiap mahasiswa mestinya diwajibkan untuk ikut UKM Dharma Gita dan Dharma Wacana, sehingga mahasiswa memiliki modal kedepannya dalam terjun ke masyarakat.

Wujud pawongan dilakukan dengan membangun komunikasi yang baik antara penyelenggara pendidikan di Perguruan Tinggi, mahasiswa dan orangtua. Kesan yang dibangun selama ini di Perguruan Tinggi Hindu antara mahasiswa dan penyelenggara pendidikan, komunikasi terbatasi oleh status dan egoism dari penyelenggara pendidikan. Mahasiswa dianggap memiliki status yang lebih rendah, sehingga terkesan mahasiswa tidak terlayani dengan baik. Komunikasi antara penyelengara pendidikanpun dengan orangtua pun seakan terputus. Guna meningkatkan pelayanan kedepan, kondisi ini harus dirubah dan mulai diefektifkan komunikasi yang menempatkan ketiga komponen ini dalam status yang sejajar 
dengan tidak meninggalkan sikap susila dan kesopanan.

Palemahan dibangun dengan mengajak mahasiswa melaksanakan keagamaan ritual keagamaan yang berkaitan dengan keselarasan lingkungan seperti mecaru dan sebagainya. Mahasiswa juga diajak untuk turut serta menjaga lingkungan agar tetap bersih dan bersikap ramah terhadap lingkungan.Kesan yang terbangun selama ini, oleh karna sudah ada cleaning service, maka mahasiswa tidak peduli terhadap lingkungan sekitarnya. Beberapa mahasiswa bahkan bertindak sembarangan dengan membuang sampah sembarangan. Kondisi lingkungan tidak terjaga dengan baik, termasuk fasilitas umum seperti wc dan sebagainya. Kondisi ini menunjukkan tingkat spiritual mahasiswa yang masih rendah. Pembangunan karakter mahasiswa dapat dibangun secara bersama oleh penyelenggara pendidikan. Mahasiswa bukanlah seorang anak kecil yang bisa dikerasi dan ditakuttakuti. Namun juga perlu diingat bahwa mahasiswa disemester awal bukanlan anak yang berpikiran dewasa yang berpikiran mandiri. Diperlukan langkah yang benar dalam membina mahasiswa di semester awal, disatu pihak penyelenggara pendidikan tidak memperlakukannya seperti anak sekolahan, namun dipihak lain juga tidak bisa memberikan kebebasan seperti layaknya manusia dewasa.

\subsection{Sinergi Orang Tua dan Perguruan Tinggi Hindu Dalam Peningkatan Mutu Perguruan Tinggi}

Tolak ukur peningkatan mutu Perguruan Tinggi dapat dilihat dari bagaimana proses belajar mengajar yang berlangsung diarahkan. Proses belajar yang berlangsung di kampus seharusnya memberikan jaminan mutu pada ketiga faktor kompetensi knowledge, skill, dan attitude. Dalam membangun ketiga faktor kompetensi tersebut diperlukan profesionalisme tenaga pengajar, fasilitas yang memadai serta suasana kampus yang kondusif. Guna mewujudkan profesionalisme tenaga pengajar, fasilitas yang memadai serta suasana kampus yang kondusif, tidak bisa lepas dari peran orangtua dan Perguruan Tinggi Hindu. Peran orangtua dalam membantu pendanaan untuk keberlangsungann pendidikan di perguruan tinggi tidak bisa diabaikan. Dilain pihak, Perguruan Tinggi Hindu perlu mengoptimalkan pendanaan dengan arif dan bijaksana. Perguruan Tinggi Hindu harus menghindari opini masyarakat terhadap komersialisasi dalam dunia pendidikan. Apalagi Perguruan Tinggi yang bernafaskan agama, apabila tidak dikelola dengan baik akan memberikan pencitraan buruk bukan hanya kepada instansi namun juga umat yang diwakilinya.

Kesan yang dibangun selama ini dalam Perguruan Tinggi Hindu adalah kurangnya peran serta orangtua dalam memberikan ide dan gagasan guna peningkatan mutu pendidikan. Guna memberikan ruang yang lebih besar bagi orangtua untuk berpean serta dalam meningkatkan mutu Perguruan Tinggi Hindu, perlu dioptimalkan organisasi yang melibatkan orangtua mahasiswa seperti organisasi ikatan orangtua mahasiswa. Organisasi ikatan orangtua mahasiswa sebagai bentuk peran serta orangtua dalam membangun kampus perlu diefektifkan. Dengan adanya organisasi semacam ini, maka orangtua akan dapat berperan dalam memberikan sumbangsih dana maupun pikiran yang lebih besar.

Ikatan Orangtua Mahasiswa merupakan wadah komunikasi dalam meningkatkan mutu Perguruan Tinggi Hindu. Pada kondisi tertentu, orangtua terlibat dalam membangun mutu kampus dengan menghindarkan kesan oposisi. Kondisi seperti ini hanya terjadi bila Perguruan Tinggi Hindu telah memiliki kematangan kondisi secara internal dalam menyelenggarakan pendidikan, merubah tatanan dan pola berpikirnya, mengedepankan demokrasi, keterbukaan, dan akuntabilitas serta prinsip-prinsip lainnya yang dilaksanakan secara komperhensif. Sinergi yang dibangun antara orangtua dan 
Pendidikan Tinggi Hindu bersentuhan dengan identifikasi lingkungan strategis yang merupakan potensi awal untuk menuju potensi yang diinginkan dimasa yang akan dating guna peningkatan mutu Perguruan Tinggi Hindu. Dalam jangka pendek, sinergi yang dibangun diharapkan dapat merubah pola pikir dan pola tindakan baik orangtua maupun penyelenggara pendidikan guna peningkatan pelayanan prima terhadap mahasiswa.

Penyelenggaraan pendidikan pada Perguruan Tinggi Hindu diarahkan pada prinsip-prinsip keterbukaan, demokratis, tercapainya guna dan daya, cepat tanggap, partisipatif, berwawasan kedepan, penegakan hokum, akuntabilitas, keadilan dan profesionalisme. Prinsip-prinsip tersebut harus dilaksanakan secara seimbang. Apabila penyelenggara pendidikan di perguruan tinggi mengabaikan beberapa prinsip tersebut, akan menimbulkan ketidakseimbangan yang berdampak pada menurunnya mutu pelayanan Perguruan Tinggi.

Ikatan orangtua mahasiswa berperan dalam menyerap keluha yang terjadi di lingkungan masyarakat kampus, dan menjadikan masukan sebagai koreksi kearah perbaikan mutu pendidikan di Perguruan Tinggi Hindu. Dengan cara apa dan bagaimana masalah yang muncul dikomunikasikan dengan penyelenggara perguruan tinggi, untuk dicarikan solusi guna perbaikan kedepan. Pada tingkat Perguruan Tinggi, perlu melakukan langkah strategis dalam memahami manfaat suatu perubahan perbaikan dengan memperhatikan mekanisme layanan pengaduan masyarakat di masa depan. Keluhan masyarakat sebagai kritik, koreksi, evaluasi perlu diperhatikan penyelenggara pendidikan di Pendidikan Tinggi Hindu.

\section{KESIMPULAN}

Membangun sinergi orangtua dan Perguauan Tinggi Hindu ibarat membangun jembatan antara dua tempat yang dipisahkan oleh sungai. Sebelumnya keduanya sudah terhubung namun untuk sampai harus mempergunakan sampan yang memerlukan waktu lama. Kesadaran antara kedua komponen ini untuk saling bersinergi akan membawa peluang semakin besar untuk menciptakan iklim pembelajaran yang baik serta kemajuan Perguruan Tinggi kedepan. Sebagaiman membangun sebuah sinergi yang baik antara orangtua dan Perguauan Tinggi Hindu, harus dipahami bahwa orangtua memiliki kewajiban untuk mengetahui bagaimana Perguruan Tinggi Hindu membangun visi dan misinya. Ikatan Orangtua Mahasiswa merupakan wadah komunikasi dalam meningkatkan mutu Perguruan Tinggi Hindu. Pada kondisi tertentu, orangtua terlibat dalam membangun mutu kampus dengan menghindarkan kesan oposisi.

\section{DAFTAR PUSTAKA}

Joko Triloka. 2007. Pendidikan Tinggi dalam Kompetisi Global. http:// www.manajemen pendidikantinggi.net/ index.php/opini/21-opini/197pendidikan-tinggi-dalam-kompetisiglobal. Diakses tanggal 5 Juli 2015.

Hasbullah, 1997. Otonomi Pendidikan. Jakarta. Pt Raja Grafindo Persada.

Suparta, I Komang. 2012.Perlindungan Anak Menurut Sumber-Sumber Agama Hindu. http://ikomangsupartahukumagama hindu.blogspot.com/ 2012/ 03 /bab-i-pendahuluan-1.html. Diakses tanggal 5 Juli 2015.

Wasty, Soemanto. 2006. Psikologi Pendidikan. Jakarta: Rineka Cipta. 